\title{
Lichen colonization of the Roman pavement at Baelo Claudia (Cadiz, Spain): biodeterioration vs. bioprotection
}

\author{
X. Ariño*a , J.J. Ortega-Calvo ${ }^{\text {a }}$ A. Gomez-Bolea ${ }^{b}$, C. Saiz-Jimenez ${ }^{a}$ \\ a Instituto de Recursos Naturales y Agrobiologia, C.S.I.C., Apartado 1052, 41080 Seville, Spain \\ ${ }^{b}$ Departament de Biologia Vegetal, Facultat de Biologia, Universitat de Barcelona, 08028 Barcelona, Spain
}

\begin{abstract}
This paper describes the effect of lichen colonization on the first century A.D. pavement of the forum at Baelo Claudia, a Roman city located in southern Spain. Lichen colonization is scarce, covering only $13 \%$ of the total surface. The rest of the flagstones are mostly uncovered but show strong physico-chemical weathering. The flagstones colonized by lichens do not show weathering. The distribution of the species is influenced by environmental factors, confirming the role of lichens as bioindicators of different habitats. The lichen/sandstone interface shows some weathering, but nevertheless, the protective role of lichens in an aggressive environment is noticeable.
\end{abstract}

Keywords: Baelo Claudia, Roman pavement, flagstones, lichen colonization, biodeterioration; Bioprotection

\section{Introduction}

The Roman city of Baelo Claudia was founded in the second century B.C. Its economy was based on fishing from the Strait of Gibraltar, especially tuna, and its trade made it one of the wealthiest cities in the Mediterranean.

Towards the end of the first century its productivity and prosperity diminished with the general decline of the Roman Empire. However, the city continued its activity and trade until the end of the fifth century when it was abandoned due to its geographical situation, away from commercial

\footnotetext{
${ }^{*}$ Corresponding author.
}

routes. It was discovered in 1917 and excavations began.

The forum of the city, after excavation in 1971, appeared relatively well preserved. However, there has been a gradual deterioration process on its paving flagstones after 20 years of exposure. The presence of moderate lichen growth on some flagstones cannot be used to explain the process, although the role of saxicolous lichens in the biodeterioration of stone has been recognized [1-4]. On the contrary, it appeared there was a protective effect on the stones through formation of a dense cover on the surface, isolating it from a harsh environment $[5,6]$. The aim of this study is to understand the factors controlling colonization 
and distribution of lichens on the sandstone of the forum, and to identify the biodeterioration processes. Biodeterioration vs. bioprotection mechanisms are also discussed.

\section{Material and methods}

\subsection{Site description}

The Roman city of Baelo Claudia is situated in the south of the province of Cadiz, Spain, between Tarifa and Zahara de los Atunes, on the Atlantic ocean coast, approximately $50 \mathrm{~m}$ from the shore. The climate is dry but mild, with relatively heavy rainfall in winter, although in summer it undergoes long periods of aridity. Strong, persistent winds blow all year, mainly from the SE and W, and there are only $2-5 \%$ days of calm per year.

The excavated city, constructed mainly in the first century A.D., is protected by walls and comprises theatre, forum, basilica, temples, thermae, macellum, tabernae, decumanus maximus, cardo maximus, necropolis, aqueduct and garum factories.

The forum (Fig. 1) is a square of $30 \mathrm{~m} \times 35 \mathrm{~m}$ paved with sandstone flagstones which present a very deteriorated aspect.

\subsection{Identification of lichen species}

Most lichens were identified directly in the forum, although some samples were collected from the pavement. They were studied in the laboratory and species were identified or confirmed according to Clauzade and Roux [7] and Navarro-Rosinés [8]. Abundancy was also taken into account.

\subsection{Analysis of the substratum}

Bare sandstone samples were collected to analyze the mineral composition. These analyses were carried out by X-ray diffraction. In addition, sandstones with lichen cover were analyzed to study possible alterations in mineral composition.

To determine the mineral matter contained in the lichens, pieces of sandstone measuring $1 \mathrm{~cm}^{2}$ and covered by Lecanora albescens or Caloplaca variabilis thalli were treated with hydrogen peroxide to destroy the organic matter. The residual mineral matter was weighed.

The material obtained by scraping a superficial orange patina formed after death and disappearance of lichen thalli was also studied by infrared spectroscopy in $\mathrm{KBr}$ discs.

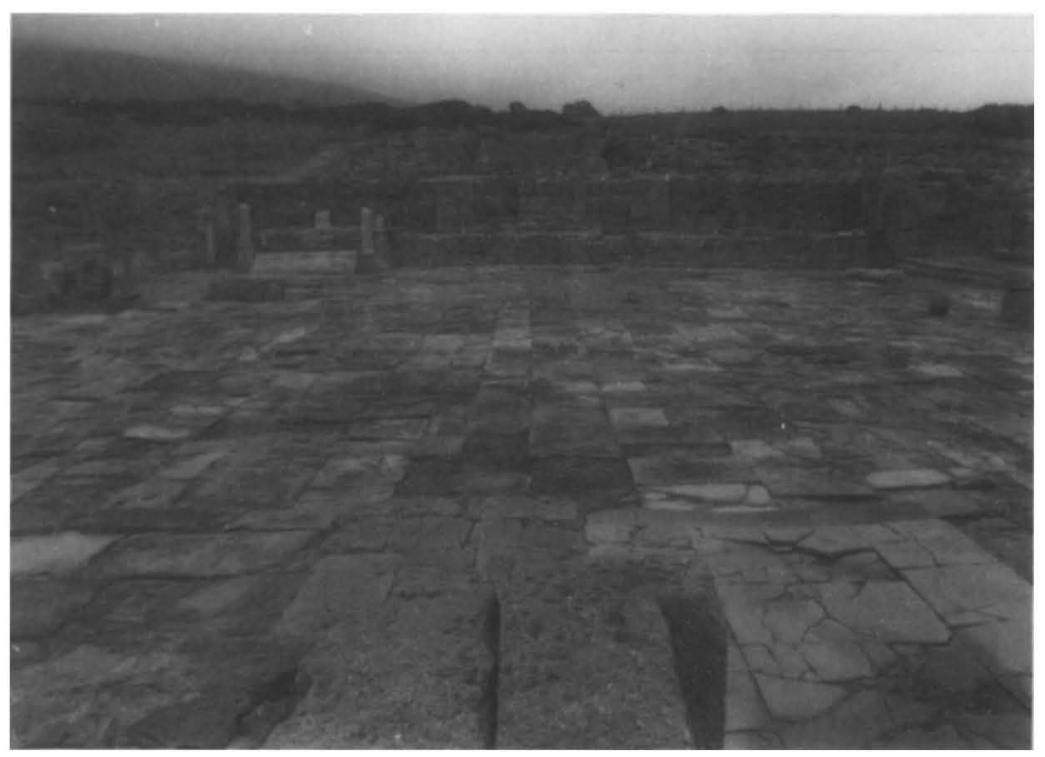

Fig. 1. The forum of Baelo Claudia. 


\subsection{Scanning electron microscopy}

Samples were fixed in a solution of $1 \%$ glutaraldehyde in $0.01 \mathrm{M}$ phosphate buffer. After subsequent fixing in osmium tetroxide $(1 \%)$, samples were dehydrated in a graded series of ethanol $(50-100 \%)$, submerged in amyl acetate, dried in a critical point drier and gold coated. A Hitachi $\mathrm{S}-2300$ microscope operating at $15 \mathrm{kV}$ was used.

\section{Results and discussion}

\subsection{Lichen colonization and distribution}

The flagstones in the forum are of a slightly bioclastic sandstone, with calcite cement. They are composed of quartz (50\%), feldspar (2\%), mica $(3 \%)$, opaque minerals $(2 \%)$, biotite, chlorite and tourmaline $(1 \%)$, fossils $(10 \%)$, peloids $(7 \%)$, and calcite cement $(25 \%)$. Crystals of quartz have an average size of $0.1 \mathrm{~mm}$ [9].

The importance of soluble salts, mainly $\mathrm{Cl}^{-}$, must be considered in weathering, as a high correlation is expected between salt concentration in stone and proximity to the sea, concentration increasing as distance decreases. This was also reported by Theoulakis and Moropoulou [10]. Salt crystallization processes on the flagstones together with the influence of the strong and persistent winds incorporating considerable amounts of airborne sand particles exert an abrasive effect on the surface of stone and lichens.

While strong physico-chemical weathering patterns (e.g. alveolization, pulverization, exfoliation, etc.) are evident on the flagstones free from lichen colonization $(87 \%$ of the total surface of the forum), these alterations are not observed in the flagstones covered by lichen communities.

Major lichen colonization is restricted to two lines of flagstones at both sides of the forum (west and east orientations, which would be indicative of different environmental conditions). In fact, these two lines coincide with the drainage system of the forum. The colonized flagstones have an air chamber beneath (Fig. 2a), which stabilizes the stone and permits the passage of water and/or salts, avoiding their accumulation and subsequent recrystallization. The remaining forum flagstones are deposited on a soil with impermeable horizons of loamy clays [11] which produce almost permanent water retention and salt mobility by ascent and descent of capillary water, contributing to deterioration due to dissolution-crystallization processes (Fig. 2b). This is especially evident on the flagstone surface, at the stone-atmosphere interface, where there is a maximum evaporation and salt precipitation, even forming efflorescences, frequently associated with descamation processes [12]. This is reflected in the extent of weathering of bare flagstones, and consequently in the difficulty for lichen establishment due to substratum instability, as colonization by lichens depends basically on the existence of stable sites where spores and propagules can install and germinate [13].

In addition, there are some randomly distributed flagstones on which lichen communities have also developed. Some of these are raised from the floor (Fig. 2c) - which has been attributed to paleoseismic effects [14] - permitting air and water diffusion from top-to-bottom, and to a certain extent explaining their conservation. They support similar colonization to that of the flagstones over the drainage, in accordance with the same mechanism. Finally, there are a few scattered flagstones deposited over the soil which are also colonized.

Twenty-two lichen taxa have been identified in the forum of Baelo Claudia (Table 1). Caloplaca species are the most common in the forum, as they seem to be well-adapted to alkaline substrata and the sunny environment. The most abundant species are Caloplaca velana, Lecanora albescens, Aspicilia contorta ssp. hoffmanniana, Caloplaca variabilis, Verrucaria macrostoma, Collema crispum var. metzleri and Lecania turicensis.

The predominant thallus morphology is crustose, and of which two are placodioid species. In addition, one species has a foliose thallus (Xanthoria calcicola) and another has scattered squamules (Collema crispum var. metzleri). Dominance of crustose thalli can be considered typical on rocks in arid environments, representing a morphology well-adapted to preventing physical alteration and avoiding an excessive water loss. 


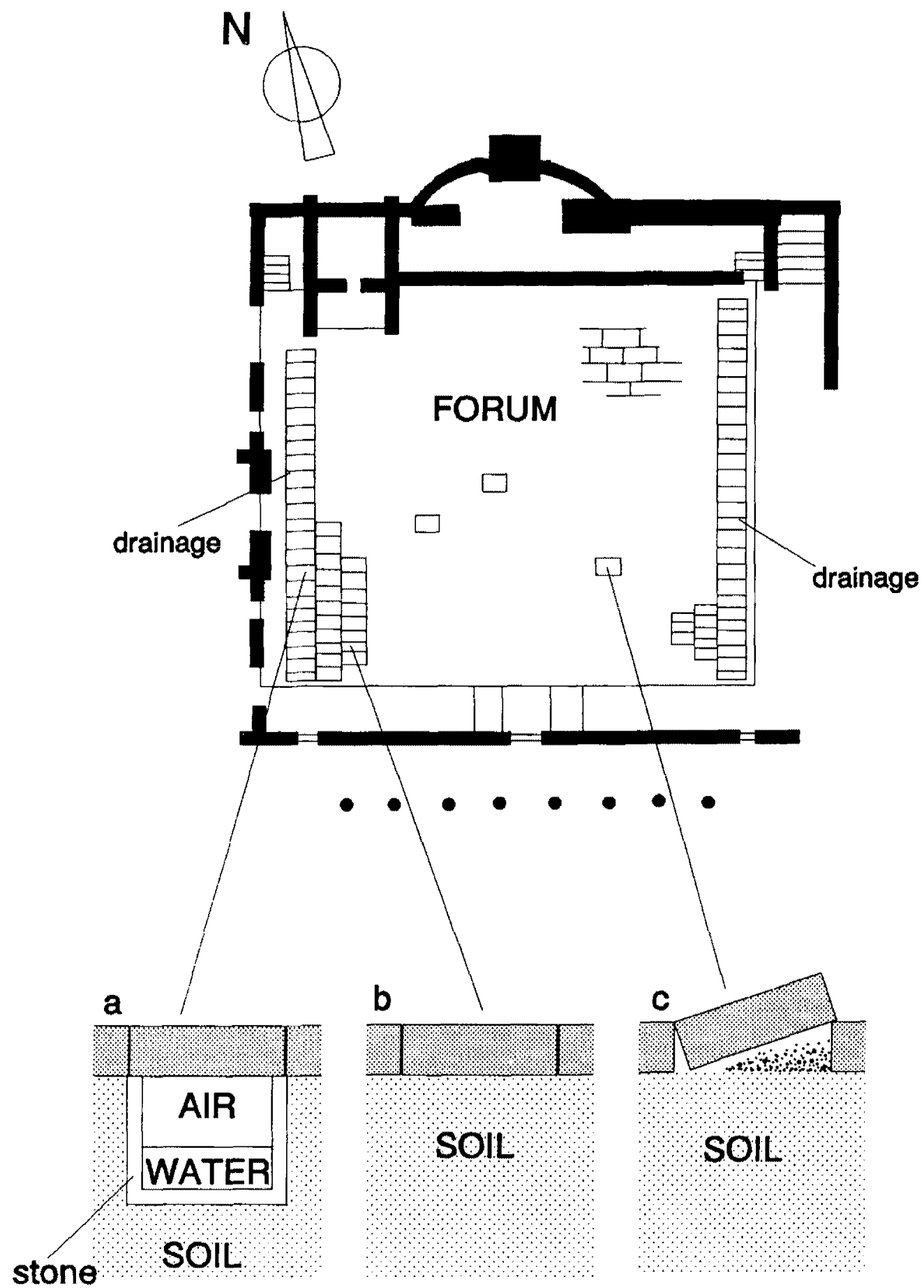

Fig. 2. Forum of Baelo Claudia; (a) flagstones covering the drainage system; (b) flagstones in direct contact with the clayey soil and (c) deformations. 
Table 1

Lichens from the forum of Baelo Claudia

Species

Unweathered

Weathered

sandstone $^{\text {a }}$

sandstone $^{\mathrm{b}}$

Aspicilia contorta ssp. hoffmanniana Ekman \& Froberg

Caloplaca aurantia (Pers.) Hellb.

Caloplaca citrina (Hoffm.) Th. Fr.

Caloplaca erythrocarpa (Pers.) Zw.

Caloplaca flauescens (Huds.) Laund.

Caloplaca lactea (Massal.) Zahlbr.

Caloplaca marmorata (Bagl.) Jatta

Caloplaca teicholyta (Ach.) Steiner.

Caloplaca variabilis (Fr.) Müll. Arg.

Caloplaca velana (Massal.) Du Rietz.

Collema crispum var. metzlen (Arnold) Degel.

Lecania turicensis (Hepp) Müll. Arg.

Lecanora albescens (Hoffm.) Branth et Rostrup.

Lecanora dispersa (Pers.) Sommerf.

Rinodina gennarii Bagl.

Sarcogyne regularis Körb. var. regularis

Thelidium olivaceum (Fr.) Körber

Toninia aromatica $(\mathrm{Sm}$ ) Massal.

Verrucaria gr. helveticonum Zehetl.

Vernucaria macrostoma Duf, ex DC.

Verrucaria muralis Ach.

Xanthoria calcicola Oxner

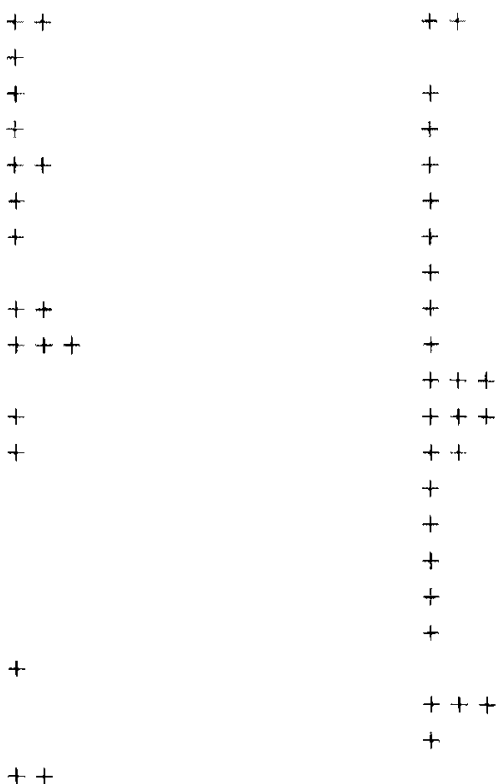

+++ , very abundant; ++ , abundant; + , scarce.

${ }^{3}$ Flagstones over the drainage system or raised from the soil.

${ }^{b}$ Flagstones deposited on the clayey soil.

The presence of numerous thalli with superficial abrasions, which can lead to the disappearance of the upper cortex or even the medula of the lichen, is evidence of the aggressive environment (mainly wind abrasion), confirmed also by the remarkably deteriorated aspect of the surface of the flagstones without lichen cover.

Most thalli are intensely coloured with yellow, red, brown or black pigments. Their role protecting the photobiont from an excess of insolation is obvious [15]. The lichen community on the drainage flagstones (and on the raised ones) is dominated by light pigmented species (yellow or orange) or with pruinose aspect (due to accumulation of calcium oxalate crystals on their surface). Otherwise, the community on the flagstones on the soil is dominated by dark pigmented species (brown or black).

Differences in the aspect of the communities and in their species composition is related to the degree of alteration of the flagstones (Table 1). The flagstones located over the drainage or raised from the soil are dry and compact. The remaining flagstones are less compact with a high amount of clay formed from the alteration, which contributes to increasing the humidity level, facilitating the growth of species such as $C$. crispum var. metzleri, a comophytic lichen, which needs some soil accumulation and humidity to grow. Its presence on the flagstones reveals that a considerable process of disintegration or cracking has occurred, and can be used as a bioindicator of heavy stone deterioration.

When the lichen community is developed, the flagstones do not show obvious weathering on their surface, indicating a protective effect of the lichen thallus, buffering the effect of the environment and diminishing physical and chemical weathering, mainly wind abrasion, raindrop impacts, water flow, changes in temperature and salt 
deposition. However, this protective effect is subsequent to the establishment of appropriate conditions for lichen colonization.

\subsection{Sandstone weathering}

Although bioprotection is noticeable, a study of the thallus-stone interface reveals typical lichen attack. A decreasing gradient in hyphal density from the thallus to a few mm depth in the stone is observed. On the surface a dense hyphal and algal network surrounds sandstone particles which are integrated into the lichen after development of the thallus. A similar process has been observed in initial development of Caloplaca aurantia [16]. To get an idea of the extent of such process, the mineral matter contained in the thallus of $C$. variabilis and $L$. albescens was weighed after organic matter digestion. Average values of 25 and $31 \mathrm{mg} \cdot \mathrm{cm}^{-2}$, respectively were obtained. This was composed mainly of quartz crystals but also calcium carbonate and calcium oxalate. The considerable amount of mineral matter found as part of lichen thalli can be interpreted as a consequence of growth: in the early stages of coloniza- tion the hyphae extend through the surface crystals and surround them (Fig. 3), so that finally they remain embedded into the thallus (Fig. 4). At the same time, in the lower part of the thallus, there is a layer with a dense hyphal network mixed with stone grains, weakening the cement holding the crystals together. Finally, the hyphal network substitutes the calcite cement and the grains are entrapped, becoming part of the thallus.

Hyphae penetrate into the stone through intercrystalline spaces or by dissolution of the calcite cement, and are usually found surrounded by a thick concretion of carbonate and oxalate. Chemical attack of the mycobiont (fungal partner of the lichen) is reflected mainly in the excretion of oxalic acid, which reacts with the calcite cement to produce calcium oxalate crystals $[17,18]$. In the interface between the sandstone and $L$. albescens, the composition of the stone is altered by the lichen activity as shown in the X-ray diagrams of unweathered stone and lichen/stone interface. The concentration of calcium carbonate decreases, as well as those of feldspar and

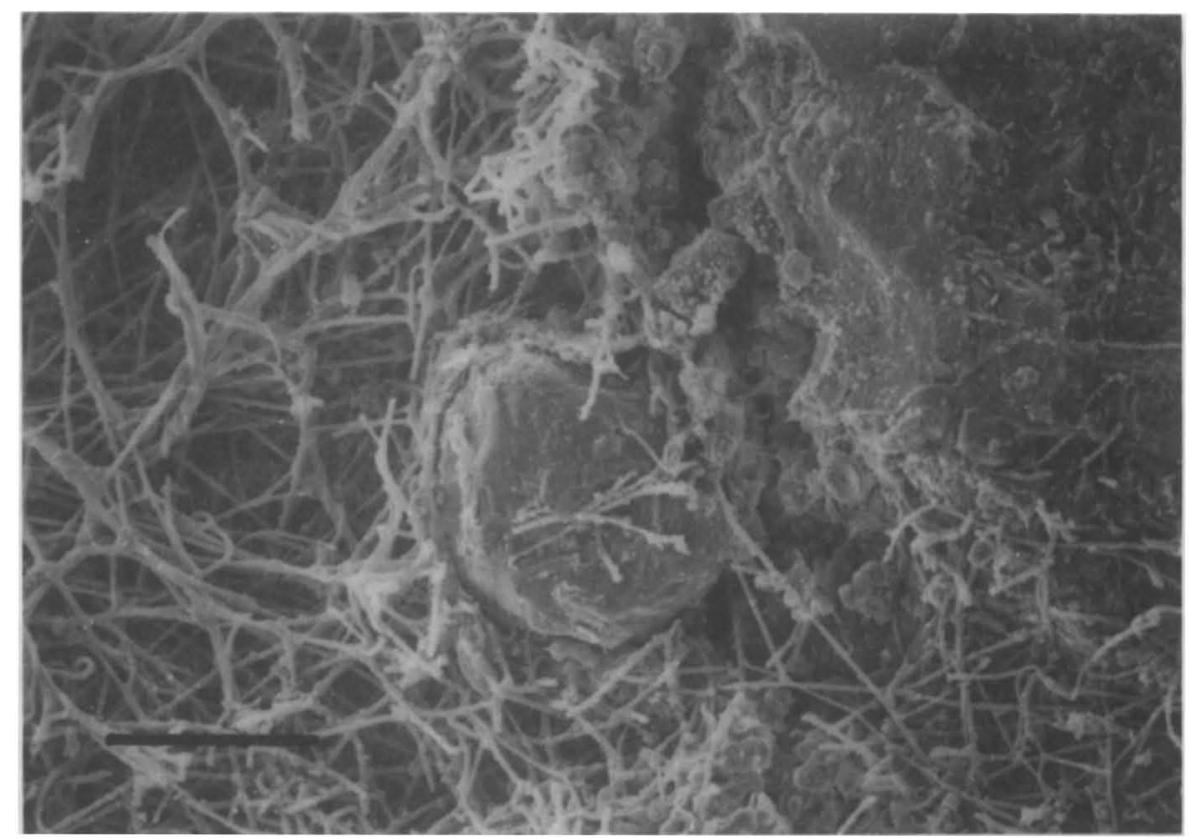

Fig. 3. Hyphal network penetrating the sandstone. The grains are surrounded by hyphae and pulled out. 


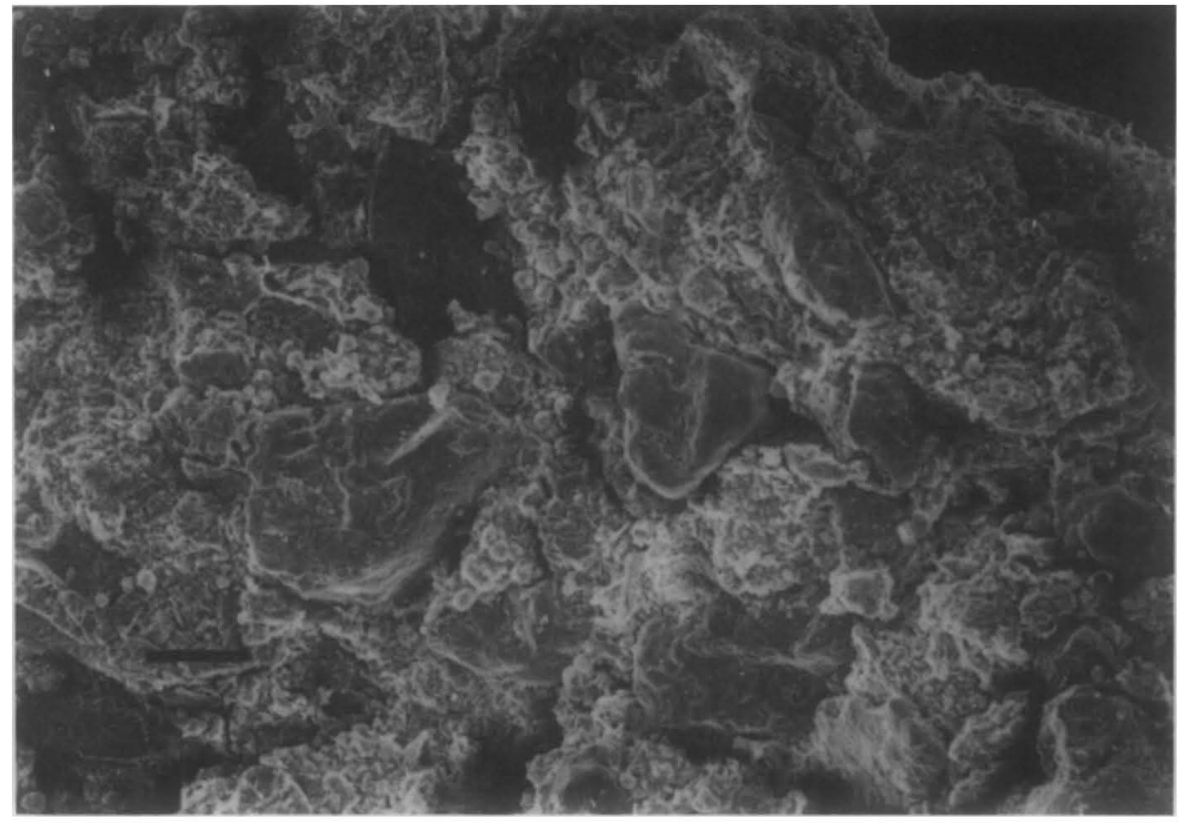

Fig, 4. Sandstone grains entrapped by the thallus.

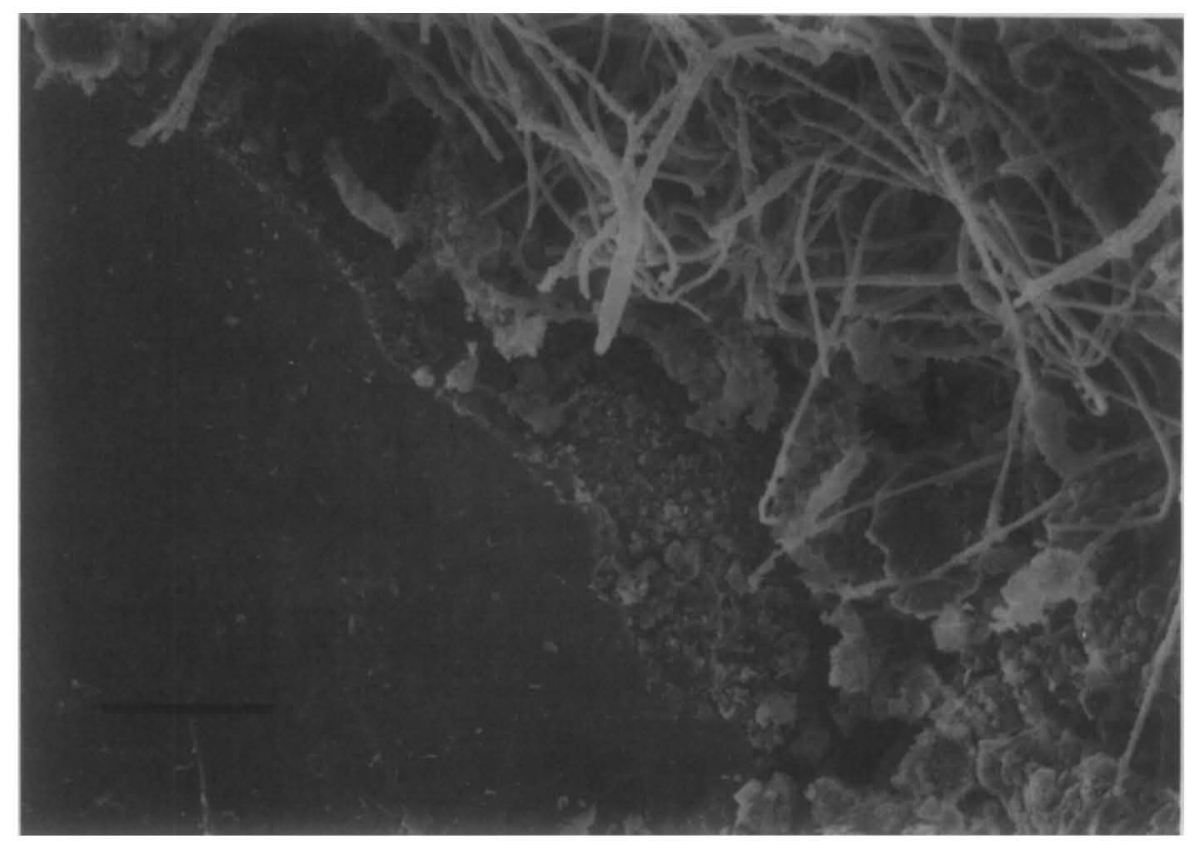

Fig. 5. Quartz grain surrounded by the thallus and subjected to chemical attack on its surface. 


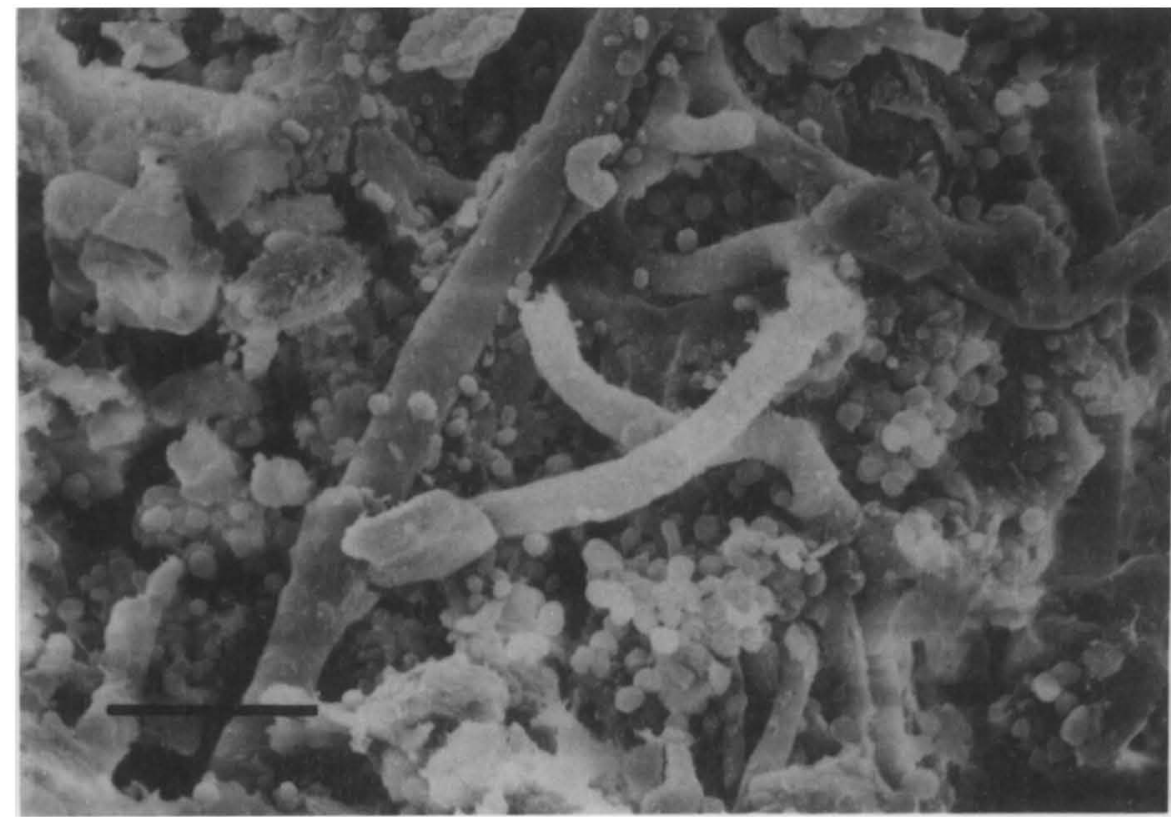

Fig. 6. Aspect of the community composed of hyphae, algae and associated heterotrophic microorganisms, under the thallus of the lichen.

mica, whilst quartz appears to be more or less constant. In fact, only traces of calcium carbonate are detected in the X-ray diagram from samples taken from the interface, whilst a high concentration of calcium oxalate, both as weddellite and whewellite (monohydrated and dihydrated form), is present (Fig. 7).

In the superficial layers, the quartz grains are surrounded by the thallus and subjected to direct chemical attack by organic acids, producing corrosion and etching on their surfaces, as shown in Fig. 5. Alteration of quartz crystals by the action of lichens has been described by Hallbauer and Jahns [19].

Beneath the thallus, an associated microbial population around the hyphae can also be found. Hollows and fissures beneath the thallus represent a protected microniche, with stable conditions of humidity and temperature. In this context, and because sufficient light is provided, a photoautotrophic community can develop, composed mostly of cyanobacteria (but also some green algae). At the same time, there is a considerable accumulation of organic matter, origi- nating from dead microorganisms and cell excretions, enabling a heterotrophic bacterial population to thrive, especially around the hyphae or closely associated with them (Fig. 6). The presence of these associated communities could represent a synergist effect of the lichen thallus, increasing biological activity and deterioration processes.

Finally, in some samples, a superficial orange patina about $0.1 \mathrm{~mm}$ thick was also found covering the sandstone surface. This is related to a previous lichen colonization, as calcified debris of thallus can be found. Infrared analysis revealed that it is composed mainly of calcium carbonate and oxalate (Fig. 8). Although the origin of these coloured patinas is a matter of debate [20-22], it seems clear that in the case of Baelo Claudia flagstones, they are biogenic, produced as a concretion after the lichen thallus has died, as has been suggested by some authors [21,22]. It is well-known that oxalate crystals can be formed around the lichen hyphae. When the thallus dies, remains of oxalates together with entrapped organic and mineral matter form a patina. This 


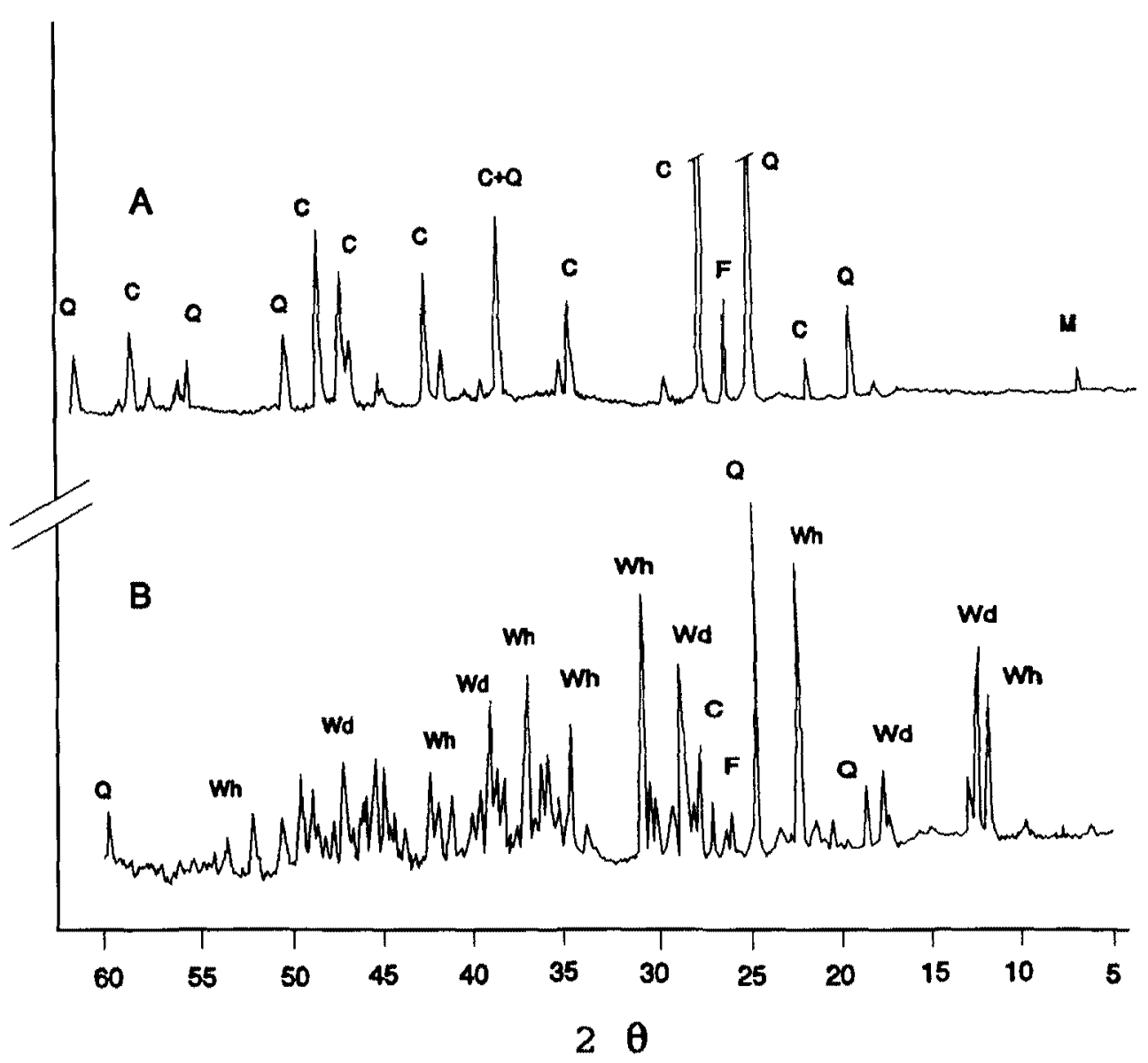

Fig. 7. X-Ray diffraction of (A) bare sandstone, and (B) interface between sandstone and Lecanora albescens. The main peaks are due to quartz (Q), calcite (C), feldspar (F), mica (M), weddellite (Wd), and whewellite (Wh),

hard, insoluble patina is also a good protection for the sandstone against weathering.

\section{Conclusions}

Biodeterioration and bioprotection are in an unstable equilibrium which can be unbalanced by environmental conditions, the substratum and the type of organisms colonizing the monuments. This is exemplified in the flagstones of the forum of Baelo Claudia, where the pavement is made of sandstone, a fragile substratum which disintegrates easily due to the combined effects of wind, salt and water.

On some flagstones there is a lichen cover. The species identified are characteristic of alkaline substrata, mainly nitrophytic (influenced by the presence of birds and other organisms) and xerophytic, with high ecological amplitude, and are frequently found in studies of monuments or areas of anthropogenic influence. At the lichensandstone interface, characteristic biodeterioration processes, namely disaggregation, calcium oxalate deposition and crystal etching have been observed. However, biodeterioration is a much slower process than physical and chemical weathering of sandstones in this particular environment, and therefore lichen structures represent a protective cover for the stones. This assumption is confirmed by the fact that flagstones without lichen cover show higher deterioration than those colonized by lichens. Protection can act at both 


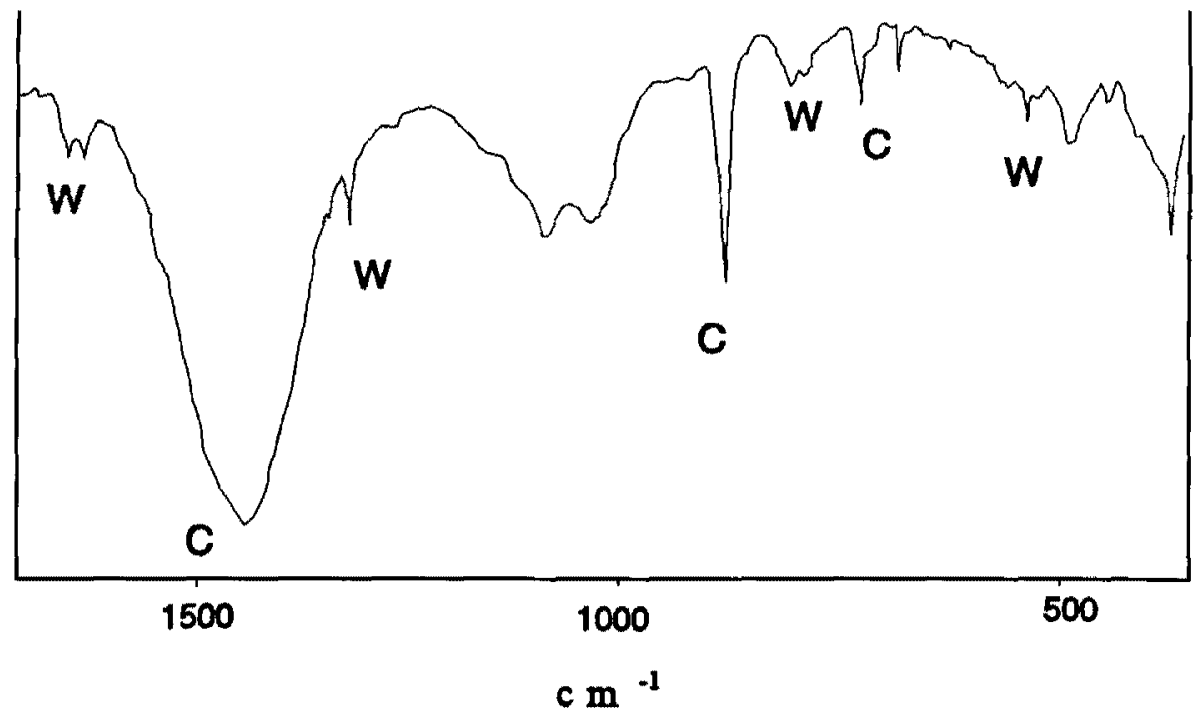

Fig. 8. Infrared spectrum of the orange patina coating the flagstone surface. Main peaks correspond to calcium carbonate (C) and calcium oxalate (W).

chemical and physical levels. In porous substrates, the presence of the lichen retards rainwater absorption, and so partially prevents dissolution and precipitation processes. Also it prevents the abrasive action produced by airborne sand particles, impact of raindrops, the dissolution effect of water lying on the surface, and prevents changes in temperature, etc.

It appears that the differential factor for preserving sandstone structure by facilitating lichen establishment is isolation from an impermeable clay ground. Air and water circulation between the upper and lower sides of the sandstone induces biological colonization and eventual bioprotection. Therefore, it seems possible that isolation of the flagstones from an almost permanently wet ground, for instance through a sand layer allowing water drainage and air circulation, would hold back the progressive and fast deterioration of the pavement.

\section{Acknowledgements}

This was a contribution from the Cooperation Agreement between the Consejeria de Cultura, Junta de Andalucia and the C.S.I.C.: 'Estudio diagnosis de los conjuntos y yacimientos arqueológicos de la Comunidad Autónoma An- daluza en su contexto geomorfológico, biológico y climático'. The facilities provided by Ms Elisa Pinilla and Mr J. Castiñeira and the technical assistance of the Electron Microscopy Service, University of Barcelona, are gratefully acknowledged.

\section{References}

[1] D. Jones and M.J. Wilson, Chemical activity of lichens on mineral surfaces. A review. Int. Biodeter., 21 (1985) 99-104.

[2] J.K. Syers and I.K. Iskandar, in V. Ahmadjian and M.E. Hale (Eds.), The Lichens, Academic Press, New York, 1973, p. 225.

[3] P.L. Nimis, M. Monte and M. Tretiach, Flora e vegetazione lichenica di aree archeologiche del Lazio. Stud. Geobot., 7 (1987) 3-161.

[4] P.L. Nimis, D. Pinna and O. Salvadori, Licheni e Conservazione dei Monumenti, C.L.U.E., Bologna, 1992.

[5] R. Lallemant and S. Deruelle, in Proceedings of an International Symposium on Deterioration and Protection of Stone Monuments, UNESCO-RILEM, Paris, 1978, p. 4.

[6] C. Gerhmann, K. Petersen and W.E. Krumbein, in 6th International Congress on Deterioration and Conservation of Stone, Supplement. Nicholas Copernicus University, Press Department, Torun, 1988, p. 33.

[7] G. Clauzade and C. Roux, Likenoj de Okcidenta Europo. Ilustrita Determinlibro. Bull. Soc. Bot. CentreOuest, No. special 7 (1985). 
[8] P. Navarro-Rosinés, Els Líquens i els Fongs Liquenícoles dels Sustrats Calcaris de la Catalunya Meridional. Ph.D. Thesis, University of Barcelona, 1992.

[9] L. Menanteau, J.R. Vanney and C. Zazo, in Belo II, Diffussion de Boccard, Paris, 1983, p. 38.

[10] P. Theoulakis and T. Moropoulou, in 6th International Congress on Deterioration and Conservation of Stone, Nicholas Copernicus University, Press Department, Torun, 1988, p. 86 .

[11] F. Borja, A. Martinez and A. Troya, El proceso historico de destruccion de la ciudad romana de Baelo Claudia (Cadiz). Caracterizacion geotecnica y analisis de formaciones superficiales. Arqueol. Espac., 16.17 (1993) 297-308.

[12] G.G. Amoroso and V. Fassina, Stone Decay and Conservation, Elsevier, Amsterdam, 1983, p. 28.

[13] R.A. Armstrong, in V. Ahmadjian and M.A. Hale (Eds.), The Lichens, Academic Press, London, 1988, p. 3.

[14] J.L. Goy, C. Zazo, N.A. Mösner, M. Hoyns, L. Somoza, T. Bardaji, P.G. Silva and C.J. Dabrio, Pop up-like deformation of a Roman floor and liquefaction structures in SW Spain as possible palaeoseismic indicators. Bull. INQUA Neotect. Commun., 17 (1994) 42-44.
[15] L. Kappen, in M. Galun (Ed.), Handbook of Lichenology, Vol. 3, CRC Press, Boca Raton, FL, 1988, p. 42.

[16] J. Garty and J. Delarea, Some initial stages in the formation of epilithic crustose lichens in nature: an SEM study. Symbiosis, 3 (1987) 49-56.

[17] D. Jones, M.J. Wilson and J.M. Tait, Weathering a basalt by Pertusaria corallina. Lichenologist, 12 (1980) 277-289.

[18] C. Ascaso, J. Galvan and C. Rodriguez Pascual, The weathering of calcareous rocks by lichens acids. Pedobiologia, 24 (1982) 219-229.

[19] D.K. Hallbauer and H.M. Jahns, Attack of lichens on quartzitic rocks surfaces. Lichenologist, 9 (1977) 119-122.

[20] V. Fassina, in The Oxalate Films: Origin and Significance in the Conservation of Works of Art. Centro CNR Gino Bozza, Milan, 1989, p. 5.

[21] C. Sabbioni and G. Zappia, Oxalate patinas on ancient monuments: the biological hypothesis. Aerobiologia, 7 (1991) 31-37.

[22] M. Del Monte, C. Sabbioni and G. Zappia, The origin of calcium oxalates on historical buildings, monuments and natural outcrops. Sci. Total Environ., 67 (1987) 17-39. 